\title{
LIMITATIONS IN THE REPRODUCTIVE SUCCESS OF A BURROW-NESTING BIRD (MOMOTUS MEXICANUS) DURING A HUMID SEASON
}

\author{
Grégory Michaël Charre ${ }^{1,2}$, Omar Paniagua ${ }^{1}$, and Marcela Osorio-Beristain ${ }^{1,3}$
}

\begin{abstract}
Burrow-nesting birds are limited by access to nest sites, particularly in years of very high humidity levels, such those seen with El Niño, or in forests that are fragmented due to the effects of human activity. We assessed the breeding success of Momotus mexicanus nesting along the earth bank of a secondary road corridor in a seasonally dry tropical forest in Central Mexico. We monitored 28 nests during the reproductive period and characterized the composition of the soil where they were constructed, as well as other physical variables. One nest produced 2 fledglings, and the other 27 failed to produce any: $46 \%$ of the nests experienced flooding or wall collapses, while the nests built on sandy loam soil remained intact. We also report other basic natural history variables for these neotropical burrow-nesting birds.
\end{abstract}

RESUMEn.-Las aves que anidan en cavidades están limitadas por el acceso a los sitios de anidación particularmente en años húmedos, como los observados con El Niño, o en selvas fragmentadas a consecuencia de la actividad humana. Se evaluó el éxito reproductivo de Momotus mexicanus que anidaron en el banco de tierra a lo largo de un camino de terracería en la selva tropical seca del centro de México. Monitoreamos 28 nidos desde la construcción hasta su abandono y caracterizamos la composición del suelo en que se construyeron y otras variables físicas. Sólo en un nido registramos dos polluelos, los otros no tuvieron éxito: el $46 \%$ de los nidos sufrieron inundaciones o derrumbes de paredes, mientras que los nidos construidos en suelo franco arenoso se mantuvieron intactos. Reportamos otras variables básicas de la historia natural de estas aves excavadoras neotropicales.

Breeding success in birds depends, in part, on environmental resources, including habitat for foraging and nesting, as well as microclimatic conditions (Lack 1968). Substrate quality is an important determinant in nest success, particularly in ecologically specialized cavity-nesting bird species. For example, birds that excavate burrow-like nests in soil often nest colonially, with the presence of suitable nest sites influencing the density of breeding birds (Yuan et al. 2006). Many burrow-nesting birds construct tunnels in sandy loam soils (Boland 2004, Yuan et al. 2006), and they appear to avoid banks composed of compacted or very loose soil (Wang et al. 2009). Consequently, breeding is limited by the availability of sandy cliffs that are soft enough to be excavated but strong enough to avoid collapse. Sandy soils also allow faster and easier nest excavation and better drainage (Brooks and Davis 1987). Moreover, sandy soils exhibit high porosity and may allow better burrow ventilation (White et al. 1978).

Nest cavity orientation is another determinant of nest success because it influences microclimate inside the nest, which is important for egg viability and energy efficiency for the nestlings and incubating adults (Webb 1987). Also, landscape fragmentation promotes edge effects that potentially reduce nest success through increased brood parasitism and nest predation (Paton 1994, Stephens et al. 2003, Deng and Gao 2005). These ecological parameters (Cornelius et al. 2008) limit nest success in cavity- and ground-nesting birds (Bisson and Stutchbury 2000, Manolis et al. 2002, Luck 2003, Cockle et al. 2010), but information is lacking regarding their influence on reproductive outputs in burrownesters. Bancroft et al. (2005) reported that in a seabird species, vegetation type above the burrow entrance influenced nest abandonment, but not reproductive success.

Russet-crowned Motmots (Momotus mexicanus) are common burrow-nesting birds regularly found in tropical dry forests in Mexico. These neotropical birds are year-round, territorial residents that use the same area for numerous years (Murphy et al. 2010). This species has highly structured population

\footnotetext{
${ }^{1}$ Centro de Investigación en Biodiversidad y Conservación, Universidad Autónoma del Estado de Morelos, 1001 Avenida Universidad, 62209, Cuernavaca, Morelos, México.

2Present address: Centro de Investigación en Ciencias Biológicas Aplicadas, Universidad Autónoma del Estado de México, Instituto Literario 100, Centro, 50000 Toluca, México.

${ }^{3}$ Corresponding author. E-mail: mosorio@uaem.mx
} 


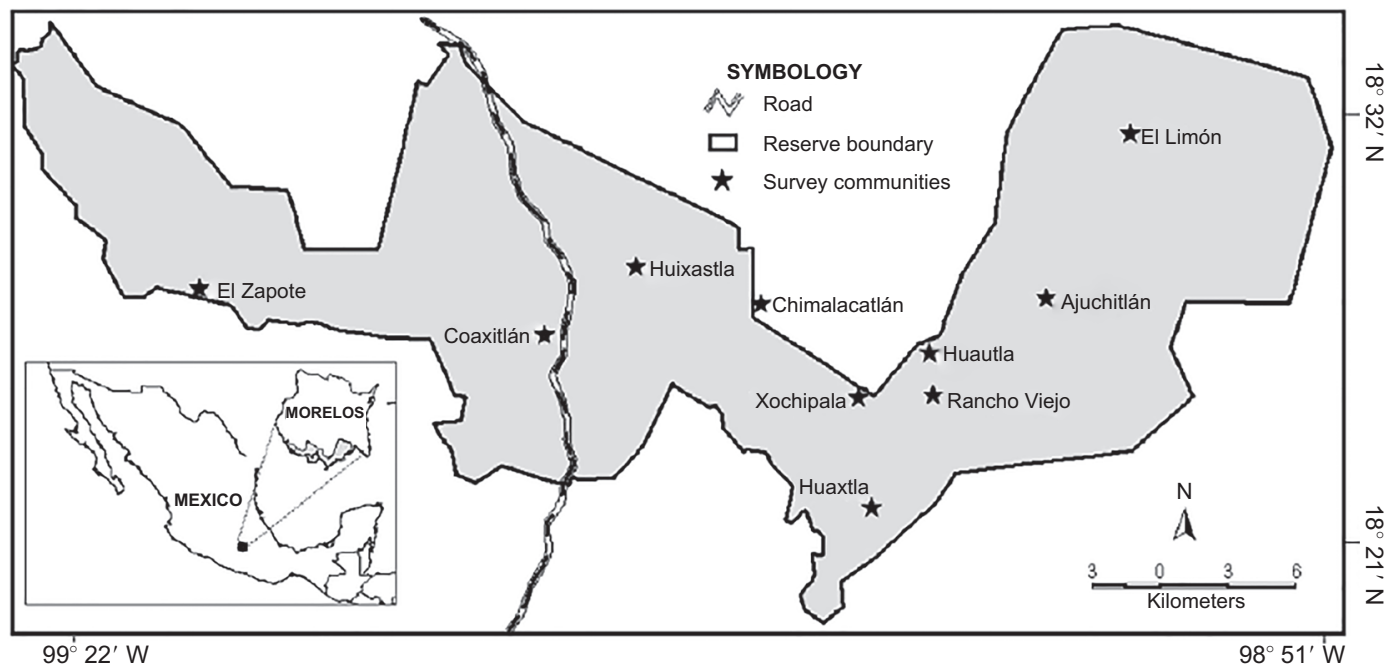

Fig. 1. Location of the study site in Morelos State, Mexico. Fieldwork was conducted near the "Estación Biológica el Limón."

genetics, possibly maintained by certain characteristics of its habitat, despite very short distances between occupied localities (Reyes et al. 2009). With both sexes excavating tunnels for nesting in earthen banks along rivers or road corridors (Howell and Webb 1995, Murphy et al. 2010), the selection of high-quality breeding sites could be a determinant of their reproductive success. Russet-crowned Motmots are long-lived organisms (living at least 11 years) that typically produce 4 -egg clutches. Murphy et al. (2010) reported 56\% nesting success from 8 pairs, but more information is needed concerning nest characteristics and their relationship to reproductive success.

In this study, we monitored the nesting success of Russet-crowned Motmots and the physical attributes of their nests in a tropical dry forest of Central Mexico during a humid season. The objectives were to (1) describe physical attributes of motmot burrows and (2) identify features that characterize intact versus collapsed nests in the reproductive outputs.

\section{MeTHODS}

We conducted our research during 2003 within the Biosphere Reserve of Sierra de Huautla $\left(18^{\circ} 26^{\prime} 21^{\prime \prime} \mathrm{N}, 99^{\circ} 01^{\prime} 27^{\prime \prime} \mathrm{W}\right)$ in southern Morelos, Mexico (Fig. 1). Elevation at the study site ranges from $900 \mathrm{~m}$ to $2700 \mathrm{~m}$ (CONANP 2005), and the vegetation is dominated by seasonally dry tropical forest (Trejo and Dirzo 2000) and agriculturally induced secondary growth vegetation (CONANP 2005). The climate is semiarid (Meza and López 1997), with temperatures ranging from $20{ }^{\circ} \mathrm{C}$ to $29{ }^{\circ} \mathrm{C}$ (García 2004). Average rainfall is $900 \mathrm{~mm}$ annually (Ramírez-Albores and Ramírez-Cedillo 2002), but precipitation is strongly seasonal with distinct dry (December-April) and rainy (May-November) seasons. In the year that this study was carried out, the oceanographic event known as the El Niño Southern Oscillation (ENSO) arrived in Mexico and could have intensified the rainy season pattern at the study site (Pavia et al. 2006)

We surveyed nesting burrows along a 15.8- $\mathrm{km}$ stretch of unpaved road from May to November. We located active nests in earthbanks dispersed alongside the roadway by observing footprints or feathers at nest entrances. Also, we assumed that a mound of fresh soil down the entrance of a tunnel signaled that the hole was being excavated. We defined a nesting pair as 2 individuals ( 1 male and 1 female) consistently present within $<15 \mathrm{~m}$ of a burrow, with at least one individual entering the tunnel. We mapped and monitored each burrow daily from its occupancy until fledging or failure. At each nest, we identified the following bird pair activities: (1) Nest excavation/re-excavation. Re-excavation occurred when a pair reused or remodeled an 


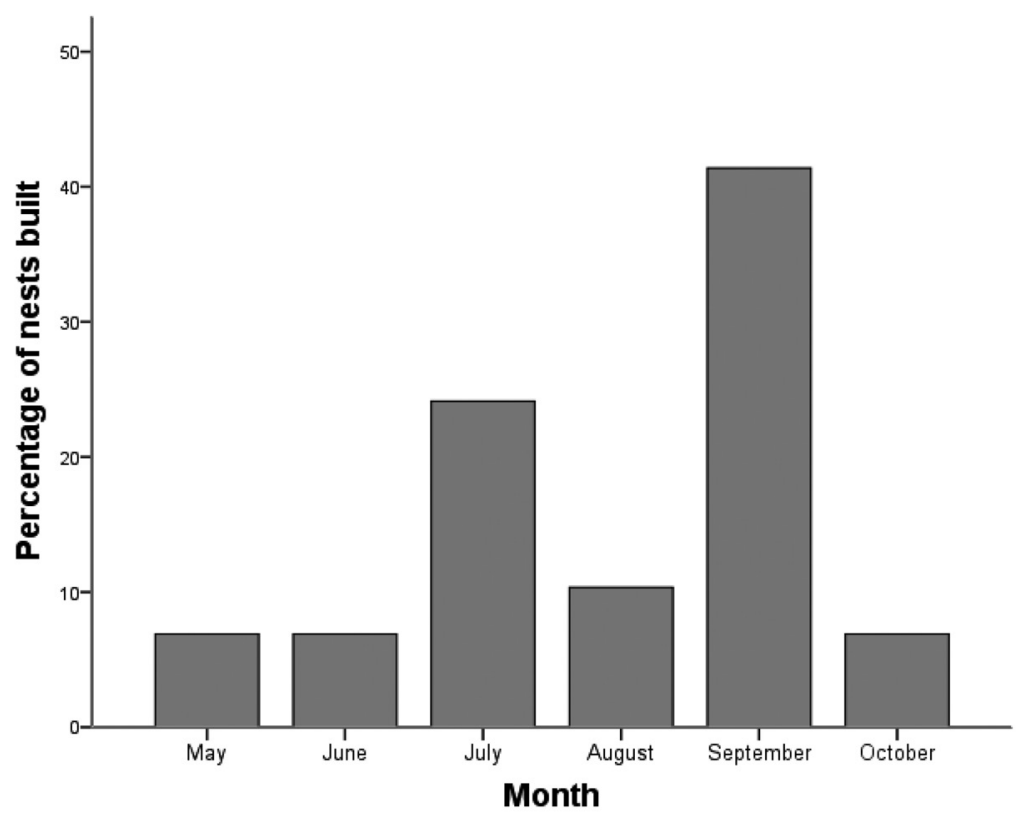

Fig. 2. Percentage of nests built by month during the 2003 breeding season of Momotus mexicanus.

existing burrow. Once these activities started, we recorded pair activity daily between 07:00 and 12:00, then between 16:00 and 20:00 (with a time lapse of $1 \mathrm{~h}$ per nest), and determined participation in the nest construction by gender. (2) Nesting period. This period was recognized when partners performed vocalizations and pendulum movements of the rectrices when researchers approached the nest. We assessed the length of time from initiation of brooding to fledgling presence and the number of fledglings surviving in each nest. We confirmed reproductive behavior by observing pairs bringing arthropods to nests and by noting the pitched sounds emitted by their offspring. (3) Chick egress. Finally, we recorded the date when chicks egressed from nests by watching the entrances of the tunnels. We then calculated the mean time of brooding since hatching. We calculated fledgling success as the ratio of nests with fledglings to total number of nests.

We recorded the following nest characteristics: nest height $(\mathrm{cm})$, entrance diameter $(\mathrm{cm})$, nest inclination degree, nest orientation, and mean distance between each nest and the nearest nest $(\mathrm{m})$. We obtained a 10 -g soil sample from $10 \mathrm{~cm}$ inside each nest in order to determine texture formation and soil type (Whiting et al. 2008).
We carried out all statistical tests using STATISTICA (version 7.0, Tulsa, OK). We report means and standard deviations unless stated otherwise. We used a chi-square test $\left(\chi^{2}\right)$ to compare precipitation amounts between 2002 and 2003 and soil composition among nests. We performed a pairwise nonparametric Mann-Whitney $U$ test on means for nest characteristics.

\section{RESUlts}

We found a total of 28 nest cavities with breeding pairs. From these, 25\% were old cavities that were re-excavated and $75 \%$ were newly made. The nest construction period principally occurred in September (42.8\%) and July (24\%; Fig. 2). Both sexes participated in nest burrow construction by digging with their beaks and removing earth with their claws.

The nesting period averaged $42.1 \mathrm{~d}$ (SD $27 \mathrm{~d}$ ), from commencement of construction or reconstruction until fledging or failure. Only 1 of the 28 nests registered 2 fledglings, corresponding to a fledging success of $3.6 \%$. The nesting period at each nest lasted almost $30 \mathrm{~d}$, with approximately $15 \mathrm{~d}$ of incubation and $15 \mathrm{~d}$ of brooding young.

Causes for nest failure were related to flooding of the burrows (32.4\%) and collapse 
TABLE 1. Characteristics of collapsed and non-collapsed nests during the breeding season of Momotus mexicanus (summer 2003). Mann-Whitney $U$ test values and significance are shown. Standard deviations are given in parentheses.

\begin{tabular}{lccl}
\hline Variable & Collapsed nest & Non-collapsed nest & Test statistic \\
\hline Height $(\mathrm{cm})$ & $145.6(63)$ & $206.66(219)$ & $U=54.5, P=0.08, n_{1}=12, n_{2}=15$ \\
Inclination (degrees) & $17.4(8)$ & $22.26(15)$ & $U=53, P=0.07, n_{1}=12, n_{2}=15$ \\
Entrance diameter $(\mathrm{cm})$ & $8.45(1.06)$ & $7.61(0.65)$ & $U=34, P=0.05, n_{1}=10, n_{2}=13$ \\
\hline
\end{tabular}

of the walls inside the nest (14.3\%). Rain promoted nest collapse because soil material became completely wet. The other nests that failed to support reproductive success $(49.7 \%)$ had no evident environmental causes of failure.

We obtained soil samples from 25 of 28 nests, since 3 nests were not accessible to the observer. Analysis of physical characteristics of the nest soils revealed that "loam" was the most common soil type (32\%), followed by "clay loam" (24\%), "sandy loam" (20\%), "sandy clay loam" (16\%) and "loam sand" (8\%). This pattern resulted in the majority of nests being constructed in soils with a higher percentage of sand $(52 \%)$, while the remainder were excavated in soils with a high proportion of silt $(29 \%)$ and clay $(19 \%)\left(\chi^{2}=16.71, \mathrm{df}=2\right.$, $P=0.0001)$. The nests ruined by rainfall were constructed in the sandy soil, while nests that were resistant to flooding were constructed in the loam soil texture.

Although there was a tendency for intact nests to be located higher than collapsed ones and to show greater inclination, nest characteristics did not differ significantly between collapsed and undamaged tunnels, except for entrance diameter $\left(U=34, P=0.05, n_{1}=10\right.$, $\left.n_{2}=13\right)$ (Table 1). Nest orientation had a higher probability of being southwesterly $(n=$ 12 cavities) than any other direction $(n=15$ cavities) $(U=20.12, P=0.0002)$. The average distance between burrows was $565.5 \mathrm{~m}$ (SD $487 \mathrm{~m})$.

\section{Discussion}

Our results suggested that Motmot reproductive success was limited by the quality of nesting grounds at our site, particularly because of high precipitation during the breeding season. Indeed, the year of this study coincided with the 2002-2003 ENSO (Climate Prediction Center 2015) in Mexico, which could have intensified the rainy season pattern at the study site (Pavia et al. 2006). Particularly, precipitation amounts were $52.4 \%$ higher than the year before, with a significant difference in the rainfall distribution among months $\left(\chi^{2}=710.30, \mathrm{df}=7, P=0.000\right.$; Fig. 3$)$.

Almost half of the monitored burrows collapsed since many of them were located in sandy soil texture. These sandy soils made the burrows more exposed to flooding during abundant rains. Structurally stronger nests that did not collapse were located on sandy loam soil and were composed of sand, silt, and clay in relatively even proportions (approximately $40 \%, 40 \%$, and $20 \%$, respectively; Schoeneberger et al. 1998). Sandy loam soils are associated with other burrow-nesting bird species, such as the Blue-tailed Bee-eater (Merops philippinus), with soil strength and compaction level in these substrates appearing to be determining criteria for nest site selection (Yuan et al. 2006).

Other nest characteristics may determine a more stable microclimate inside the burrow. Particularly, burrow or tunnel orientation and entrance diameter and height (Van Balen et al. 1982) have been shown to influence reproductive performance. Here, flooding associated with higher precipitation could be responsible for the low breeding success recorded in the study. Our data demonstrated that $46 \%$ of nests collapsed, and only one nest had 2 surviving fledglings, with $96 \%$ of the 28 nests experiencing complete failure. In the same region, a higher value of $56 \%$ fledgling success has been reported, although few nests were monitored (Murphy et al. 2010). The entrance diameter was important in nests that did not collapse, because a reduction of 1-2 cm permitted them not to ruin. The majority of the burrows had a southwesterly orientation. This could be decisive for Motmot reproduction, since orientation can enhance burrow insulation and thermoregulation.

The large distance of $560 \mathrm{~m}$ between cavities could represent an insufficient quantity of suitable nesting sites $\left(1.78\right.$ nests $\left.\cdot \mathrm{km}^{-1}\right)$ in the study area. Substrate availability influences the density of burrow-nesters like the Blue-tailed 


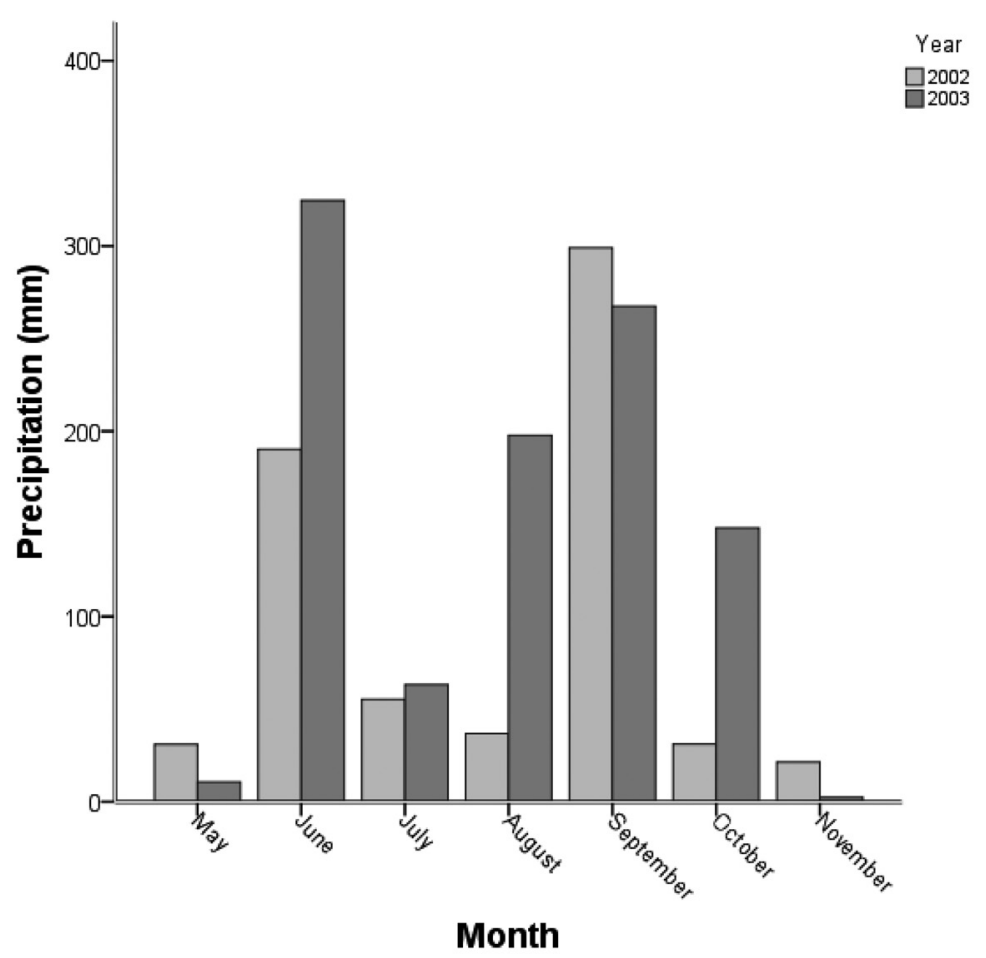

Fig. 3. Precipitation amount during the 2002-2003 breeding season of Momotus mexicanus. Data were obtained from Comisión Nacional del Agua (CONAGUA).

Bee-eater (Yuan et al. 2006) and determines the nest distribution and density for European Beeeaters (Merops apiaster), with nesting colonies separated by at least $20 \mathrm{~m}$. (See also methods in Heneberg and Šimeček 2004; for methods involving Eurasian Kingfishers [Alcedo atthis], see Heneberg 2004; and for methods involving Bank Swallows [Riparia riparia, also called Sand Martins], see Heneberg 2001 and Heneberg and Šimeček 2004.) Other territorial conspecific species (i.e., Momotus momota) with similar nest requirements aggressively defend nest banks for a 6 -m radius around the nest (Orejuela 1980). These short distances suggest that $M$. mexicanus could likely reproduce with a smaller separation between burrows than we observed, if the substrate were suitable.

The failure of other nests $(49.7 \%$, not including those that flooded and collapsed) could be explained by inadequate soil properties: (1) higher soil granulometry, since it has been observed that soil particle composition and size determine burrow nest occupancy for motmot relatives like kingfishers (Heneberg 2004, Heneberg and Šimeček 2004), (2) higher soil penetrability (Heneberg 2009), and (3) the proportion of rockfills (Vilches et al. 2012), which are abundant in the study site. According to mathematical models, geomorphology is the key factor of habitat use by burrow nesters like Belted Kingfishers (Ceryle alcyon; Sullivan et al. 2006).

Events of predation could not be inferred to contrubute to nest failure in this study, as was detected in Murphy et al. (2010), since none of the burrows showed evidence of snake or iguana tracks. A possible origin of burrow collapse may be the type of vegetation present above the burrows, like Bancroft et al. (2005) encountered. Herbaceous plants can contribute to nest collapse because their shallow roots may not stabilize the soil to an adequate depth for burrow construction, and the open area of the unpaved road could favor this vegetation.

Although we could not compare reproductive success with the previous year, we expect that an unusually high amount of rainfall during the ENSO led to low fecundity and low reproductive outputs in M. mexicanus, as has been found in various bird species (Renton and Salinas-Melgoza 2004, Nesbitt Styrsky and 
Brawn 2011). In other species, Wolfe et al. (2015) showed that El Niño has a strong effect on bird survival, depending on forest age. The combined effect of elevated precipitation and low-quality soils probably impeded nesting motmot success. We observed a second event of nest excavation in September, which may be a sign of another attempt at reproduction provoked by El Niño, because normally motmots reproduce only once per year (Murphy et al. 2010).

Moreover, nest location on an open roadside could make motmots more susceptible to weather constraints, compared to nests on natural sites like ravines where better reproductive success has been recorded (Murphy et al. 2010). General fragmentation is occurring in the seasonally tropical dry forest in Mexico (Trejo and Dirzo 2000), and modifications of natural landscapes, together with increasing precipitation, are likely to play a major role in both the loss of suitable habitats for and the low breeding performance in the Russetcrowned Motmots monitored in this study. Particularly, neotropical birds that excavate tunnels for nesting in earthbanks have received little attention compared to other burrow users (Bisson and Stutchbury 2000, Manolis et al. 2002), though habitat loss and ecological specialization could predispose burrow-nesting bird species to extinction (Bennet and Owens 2002). More specifically, road burrows did not offer good sites for motmot reproduction and could represent ecological traps in the long term.

This study could be of great importance for forest managers in helping them conserve suitable motmot habitats, with special focus on maintaining riparian corridors with substrate banks that permit the excavation of structurally strong nest-burrows or augmenting the clay proportion in sandy soil areas. Consequently, these actions should facilitate conservation of other animal species (lizards, iguanas, snakes, tarantulas), as burrows can be reused after the motmot breeding season by many other engineer species (Aitken et al. 2002, Valdivia Hoeflich et al. 2005).

\section{ACKNOWLEDGMENTS}

Thanks to J. Torres for help with fieldwork. Funding for research and equipment was provided by Consejo Nacional de Ciencia y
Tecnología project 32848 to MOB. We are grateful to supportive colleagues in the Cuerpo Académico Ecología Evolutiva del Centro de Investigación en Biodiversidad y Conservación. R. Oliver helped with the soil structure analyses.

\section{Literature Cited}

Aitken, K.E.H., K.L. Wiebe, and K. Martin. 2002. Nestsite reuse patterns for a cavity-nesting bird community in interior British Columbia. Auk 119:391-402.

Bancroft, W.J., J.D. Roberts, and M.J. Garkaklis. 2005. Burrow entrance attrition rate in Wedge-tailed Shearwater Puffinus pacificus colonies on Rottnest Island, western Australia. Marine Ornithology 33:23-26.

Bennet, P.M., AND P.F. Owens. 2002. Evolutionary ecology of birds-life histories, mating systems and extinction. Oxford Series in Ecology and Evolution. Oxford University Press, Oxford.

Bisson, I.A., AND B.J. Stutchbury. 2000. Nesting success and nest-site selection by a neotropical migrant in a fragmented landscape. Canadian Journal of Zoology $78: 858-863$.

BoLAND, C.R.J. 2004. Introduced cane toads Bufo marinus are active nest predators and competitors of Rainbow Bee-eaters Merops ornatus: observational and experimental evidence. Biological Conservation 120:53-62.

BRooks, R.P., AND W.J. Davis. 1987. Habitat selection by breeding Belted Kingfishers Ceryle alcyon. American Midland Naturalist 117:63-70.

Climate Prediction Center. 2015. ENSO, recent evolution, current status and predictions. [Accessed 7 April 2015]. http://www.cpc.ncep.noaa.gov/products/analysis _monitoring/lanina/enso_evolution-status-fcsts-web .pdf

Cockle, K.L., K. Martin, And M.C. Drever. 2010. Supply of tree-holes limits nest density of cavity-nesting birds in primary and logged subtropical Atlantic forest. Biological Conservation 143:2851-2857.

CONANP. 2005. Programa de Conservación y Manejo Reserva de la Biosfera Sierra Huautla México. Morelos, México.

Cornelius, C., K. Cockle, N. Politi, I. Berkunsky, L. Sandoval, V. OJeda, L. Rivera, and K. Martin. 2008. Cavity-nesting birds in neotropical forests: cavities as a potentially limiting resource. Ornitología Neotropical 19:253-268.

Deng, W.-H., AND W. GaO. 2005. Edge effects and nesting success of cavity-nesting birds in fragmented forests. Biological Conservation 126:363-370.

GarCía, E. 2004. Modificaciones al sistema de clasificación climática de Köppen. UNAM, Instituto de Geografía, México.

HeneberG, P. 2001. Size of sand grains as a significant factor affecting the nesting of bank swallows (Riparia riparia). Biologia 56:205-210.

Heneberg, P. 2004. Soil particle composition of Eurasian Kingfishers' (Alcedo atthis) nest sites. Acta Zoologica Academiae Scientiarum Hugaricae 50:185-193.

HeneberG, P. 2009. Soil penetrability as a key factor affecting the nesting of burrowing birds. Ecological Research 24:453-459. 
HeneberG, P., And K. Šimeček. 2004. Nesting of European Bee-eaters (Merops apiaster) in Central Europe depends on the soil characteristics of nest sites. Biologia 59:205-211.

HoweLL, S.N.G., AND S. WEBb. 1995. A guide to the birds of Mexico and northern Central America. Oxford University Press, Oxford.

LACK, D. 1968. Ecological adaptations for breeding in birds. Mathuen Co., London.

Luck, G.W. 2003. Differences in the reproductive success and survival of the Rufous Tree Creeper (Climacteris rufa) between a fragmented and unfragmented landscape. Biological Conservation 109:1-14.

Manolis, J.C., D.E. Andersen, And FJ. Cuthbert. 2002. Edge effect on nesting success of ground nesting birds near regenerating clearcuts in a forest-dominated landscape. Auk 119:955-970.

MEzA, L., AND J.L. LóPEz. 1997. Vegetación y mesoclima de Guerrero. Pages 1-53 in N. Diego-Pérez and R.M. Fonseca, editors, Estudios florísticos en Guerrero. UNAM, Facultad de Ciencias, México.

Murphy, T.G., T.E. Rohwe, and E. Scholes. 2010. Breeding biology and longevity of Russet-crowned Motmots in Central Mexico. Journal of Field Ornithology 8:13-16.

Nesbitt Styrsky, J., And J.D. Brawn. 2011. Annual fecundity of a neotropical bird during years of high and low rainfall. Condor 113:194-199.

Orejuela, J.E. 1980. Niche relationships between Turquoise-browed and Blue-crowned Motmots in the Yucatan Peninsula, Mexico. Wilson Bulletin 92:229-244.

Paton, P.W.C. 1994. The effect of edge on avian nest success: how strong is the evidence? Conservation Biology 8:17-26

Pavia, E.G., F. Graef, and J. Reyes. 2006. PDO-ENSO effects in the climate of Mexico. Journal of Climate 19:6433-6438.

Ramírez-Albores, J.E., and M.G. Ramírez-Cedillo. 2002. Avifauna de la región oriente de la sierra de Huautla, Morelos, México. Anales del Instituto de Biología, Universidad Nacional Autónoma de México, Serie Zoología 73:91-111.

Renton, K., and A. Salinas-Melgoza. 2004. Climatic variability, nest predation, and reproductive output of Lilac-crowned Parrots (Amazona finschi) in tropical dry forest of western Mexico. Auk 121:1214-1225.

Reyes, D., R. Alcala, D. Arias, and M. Osorio-Beristain, M. 2009. Genetic structuring at a fine scale in the Russet-crowned Motmot (Momotus mexicanus) in a tropical dry forest in central Mexico. Western North American Naturalist 69:171-174.

Schoeneberger, P.J., D.A. Wysocki, E.C. Benham, And D.W.D. BRoDERson. 1998. Field book for describing and sampling soils. USDA Natural Resources Conservation Service, National Soil Survey Center, Lincoln, NE.
Stephens S.E., D.N. Koons, J.J. Rotella, and D.W. WilLEY. 2003. Effects of habitat fragmentation on avian nesting success: a review of the evidence at multiple spatial scales. Biological Conservation 115:101-110.

Sullivan, S.M.P., M.C. Watzin, And W.C. Hession. 2006. Differences in the reproductive ecology of Belted Kingfishers (Ceryle alcyon) across streams with varying geomorphology and habitat quality. Waterbirds 29:258-270.

Trejo, I., And R. Dirzo. 2000. Deforestation of seasonally dry tropical forest: a national and local analysis in Mexico. Biological Conservation 94:133-142.

Valdivia Hoeflich, T., J.H. Vega Rivera, and K.E. Stoner. 2005. The Citreoline Trogon as an ecosystem engineer. Biotropica 37:465-467.

Van Balen, J.H., C.J.H. Booy, J.A. Van Franeker, and E.R. OsIEcK. 1982. Studies on hole-nesting birds in natural nest sites: 1. Availabiliy and occupation of natural nest sites. Ardea 70:1-24.

Vilches, A., R. Miranda, J. Arizaga, and D. Galicia. 2012. Habitat selection by breeding Common Kingfishers (Alcedo atthis L.) in rivers from northern Iberia. Annales de Limnologie-International Journal of Limnology 48:289-294.

Wang, Y.P., L. Siefferman, Y.J. Wang, T.S. Ding, C.R. Chiu, B.S. Shieh, F.S. Hsu, and H.W. Yuan. 2009. Nest site restoration increases the breeding density of Blue-tailed Bee-eaters. Biological Conservation 142:1748-1753.

WebB, D.R. 1987. Thermal tolerance of avian embryos: a review. Condor 89:874-898.

White, F.N., G.A. Bartholomew, and J.L. Kinnet. 1978. Physiological and ecological correlates of tunnel nesting in European Bee-eater, Merops apiaster. Physiological Zoology 51:140-154.

Whiting, D., A. CARD, AND C. Wilson. 2008. Estimating soil texture: sandy, loamy, or clayey? Colorado State University Extension Garden Notes \#214. [Accessed 1 December 2008]. http://www.cmg.colostate.edu/ gardennotes/214.pdf

Wolfe, J.D., C.J. Ralph, and P. Elizondo. 2015. Changes in the apparent survival of a tropical bird in response to the El Niño Southern Oscillation in mature and young forest in Costa Rica. Oecologia 178:715-721.

Yuan, H.W., M.K. Wang, W.L. Chang, L.P. Wang, Y.M. Cheng, and C.R. Chiu. 2006. Soil composition affects the nesting behavior of Blue-tailed Bee-eaters Merops philippinus on Kinmed Island. Ecological Research 21:510-512.

Received 19 April 2016

Accepted 4 April 2017

Published online 12 July 2017 